\title{
The Subaltern Cannot Speak: A Study of Adiga Arvinda's The White Tiger
}

\author{
Golchin Pourqoli \\ Tabriz University, Iran \\ Akram Pouralifard (Corresponding author) \\ Tabriz University, Iran \\ E-mail: pouraliheckmat@gmail.com
}

Received: 04-12-2016

Published: 01-05-2017
Accepted: 23-01-2017

doi:10.7575/aiac.ijalel.v.6n.3p.215
Advance Access Published: March 2017

URL: http://dx.doi.org/10.7575/aiac.ijalel.v.6n.3p.215

\begin{abstract}
This study examines the claims about Adiga Arvinda's anti-protagonist's, Balram Hawaie's status as representive voice of subaltern, in his controversial novel, the White Tiger (2008), which also gave way to much debate over its 'authenticity'. By alluding to postcolonial thinkers such as Edward Said, Ghandi, Spivak, and also Giorgio Agamben's notion of inclusive exclusion, the essay focuses on the evidence from the novel to indicate that there is no space from which the subaltern of the novel can be heard. The research utilizes the precepts of postcolonial criticism to examine the possibility of considering any room for the voice of the subaltern in The White Tiger for being heard. Through a close reading of the text, also, the study addresses the alterations in the character of the protagonist which ostracize him from the league of the subaltern.
\end{abstract}

Keywords: Spivak, Subaltern, Otherness, Balram, White Tiger

\section{Introduction}

Aravind Adiga's Booker Prize novel, The White Tiger, narrates the story of the protagonist, Balram Halwaie, who as a son of a very poor and extended family was born and raised in Darkness, Laxmangarh, a village along Ganga River which in his dichotomizing of India into Dark and Light, he calls it 'Dark India' (Adiga, 2008, p.10). The whole family was controlled by his grandmother, the 'sly old Kusum', of whom every son and daughter-in-law lived in fear (p.11). Balram was forced to drop out of school in order to repay the landlord from whom the family had taken a big loan in order to have a lavish wedding and a lavish dowry for his cousin-sister. He was made to work in a tea shop, since the landlord wanted all the members of the family working for him (p. 23).

After his father's death, he came in Dhanbad and started working as the number two driver for his ex-landlord's family, specifically his Americanized son, Ashok. The family was in coal trading and Mr. Ashok was called back to India in order to go to Delhi to solve some problems in their business. Over there, Balram kills him and runs away with his money. Then, he ends up as a rich and successful entrepreneur, establishing his own taxi service.

In this regard, researches done mainly on Balram identify him "as a strong voice of the underdogs who . . . shakes the very base of the social structure ... [whose] evolution symbolizes the evolution of the marginalized" (Maji, 2015, p. 352). Thus, in their studies, they "have attempted . . . to prove that "subaltern can speak" (Yadav, 2011, p. 2). Thus, in his essay "The Subaltern Can Speak: A Study of Arvind Adiga's The White Tiger”, Maji (2015) by calling Balram "a representative [voice] of "India of Darkness" declares that "Balram serves as the mouthpiece of the subaltern people who have never been allowed to speak. Balram speaks and gives voice to the voiceless through his act of selfactualization." (Maji p. 351)

However, in 1985 Gayatri Spivak, with her controversial essay 'Can the subaltern speak?' threw a challenge to the race and class blindness of the Western academy. By subaltern she meant the oppressed subject, the members of Antonio Gramsci's 'subaltern classes' or more generally those 'of inferior rank' (Gandhi, 1998, p. 1). She believes that "the subaltern has no history and cannot speak" (p. 83). Then, the main questions raised here are whether Balram Halwaie, the anti-protagonist of the novel, really represents the voice of the subaltern (of this novel) and most importantly, whether his narrative and his ability to make himself to be heard is a representative act for the subaltern of the society he depicts? Thus, the main point of this study is to answer the raised questions.

In this regard, by declaring that "I perceive that Spivak's argument is slightly related to speech than power and ability of subaltern to make them heard" Yadav (2011) concludes that Balram revolts and gets success and recognition at any cost, thus, he gives the voice to his oppressed, abused and exploited brethren (p. 6). Nonetheless, even if that is the case, this study would argue that his narrative and his ability to make himself to be heard, rather than a representative act for 
the subaltern is a self-consolidating project. Thus, neither his ability to make himself to be heard, nor his ability to occupy a powerful status as a master, can nominate him as representive voice for subaltern.

The novel, gave rise to much debate over its authenticity and whether or not the Man Booker Prize novel, complies with re-orientalist and therefore, inauthentic image and representation of India. The novel by highlighting the core issues of Indian society such as identity crisis, hybridity, class discrimination, political corruption, poverty, influence of foreign culture and degradation of traditional values etc., is accused of fabricating narratives about the poor of India chiefly for an affluent and/or western readership (Mendes, 2010, p. 286). In this sense, Edward Said also maintains that "[Oriental discourse was produced by West, in order to] represent it as the negative, underground image or impoverished 'Other' of Western rationality ... to produce stereotypes about Orientals and the Orient ... [which in turn will] confirm the necessity and desirability of colonial government by endlessly confirming the positional superiority of the West over the positional inferiority of the East" (as cited in Gandhi, 1998, p.77). In this way, Postcolonial theory is heavily dependent on and built around the concept of otherness.

In his critical analysis of the White Tiger, attending the debates over authenticity or inauthenticity of the novel, by calling Balram an 'outsider', Prateek Deswal (2014) writes,

[w] hile going to Delhi the feelings, the emotions that Balram Halwai is dealing with are not the ones which a person would have felt while moving from one part of the country to another but they seem to be the ones which a person would have felt while going to Australia or America. This fact itself lays the foundation of partial observance by a detached Indian. (p.286)

Looking into Balram's feelings - who by seeing the poor travelers packed insides, hung out the doors, and even got on the roofs of the buses, "all headed from the Darkness to Delhi" (Adiga, 2008, p. 66), while himself was going to Delhi in an air-conditioned car, declares that: "Each time we passed by one of these buses, I had to grin; I wished I could roll down the window and yell at them, I'm going to Delhi in a car-an air-conditioned car! But I'm sure they saw the words in my eyes" (p. 66) - one can easily conclude that, the emotions with which he deals are as a result of his identification with the rich, or more exactly with his ex-master, Ashok.

Back to his childhood, Balram writes about his father's dream who says "My whole life, I have been treated like a donkey. All I want is that one son of mine - at least one - should live like a man" (p.19, emphasis added). Then, Balram exclaims that "What it meant to live like a man was a mystery. I thought it meant being like Vijay, the bus conductor" (p.19, emphasis added) and continues that "he was the first entrepreneur I knew of" (p.19). Thus, he writes "I wanted to be like Vijay_with a uniform, a paycheck ... and people looking at me with eyes that said, How important he looks..." (p. 20, original emphasis). Consequently, the desire, to be like a man and to look like an important one, which is produced in Balram is the very thing that Balram is, or thinks that he is forbidden from; since, as Lacan asserts "Desire and the unconscious are founded through the recognition of a fundamental lack" (Homer, 2005, p. 72).

The same thing is also true about his feelings toward Ashok. Since "All desire arises from lack" (Evans, 2006, p. 12), in the process of his ego formation, by seeing Ashok as ideal image of himself, Balram desires to be a (whole) man like Ashok, to be a master and thus, to have "a position which was ideologically and socially restricted for him" (Yadav, 2011, p. 5). Thus, he identifies with Ashok which leads to Ashok's death and Balram's usurpation of his money and identity: "Yes, Ashok! That's what I call myself these days. Ashok Sharma, North Indian entrepreneur, settled in Bangalore" (Adiga, 2008, p.181).

Then, his identification with Ashok already done, he began to see the poor as the 'other'. This also results in his complete identification with rich which is evident in the beginning of narrating his story to Mr. Jiabao. So, he points out that "In my way, sir, I consider myself one of your kind" (p. 3). Then, as a result of his full identification with rich and the members of upper-class, he began to produce his 'other', that is, to make a clear distinction between himself and the others who remain poor. In this sense, in their essay "Use of the Animal Imagery in Adiga's The White Tiger", in their attempt to explain the reasons behind attachment of 'White tiger' to Balram, Ahmedi and Rafique (2014) write:

Throughout the novel, there are references to how Balram is very different from those back in his home environment. A white tiger symbolizes power and . . . it is also a symbol of freedom and individuality. Balram is seen as different from those he grew up with. He is the one who got out of the Darkness and found his way into the Light. (p. 5, emphasis added)

All these are very evident in the course of novel, where he boasts a lot of his abilities which he sees as the main reason for his success and others' failure. Because, while others "remain slaves because they can't see what is beautiful in this world" (Adiga, 2008, p. 25, original emphasis), as a white tiger-a creature that comes along only once in a generation - he is the only one who sees and notices the beauties in the world so that he writes: "Even as a boy I could see what was beautiful in the world: I was destined not to stay a slave" (p. 26, emphasis added). This emphasis on the distinction between him and others is also evident in the end of his story. Thus, in giving account of his business to premier Jiabao, he writes: 
Put together $m y$ real estate and $m y$ bank holdings . . . I am worth fifteen times the sum I borrowed from Mr. Ashok. See . . my Web site . . . photos of my SUVs, my drivers, my garages, my mechanics, and my paid-off policemen. All of them belong to meMunna . . . . They're my employees, I'm their boss . . If they notice the way I talk, the way I dress, the way I keep things clean, they'll go up in life. If they don't, they'll be drivers all their lives. I leave the choice up to them. When the work is done I kick them out of the office: no chitchat, no cups of coffee. (pp. 181-182, emphasis added)

So, rather than being a simple innocent piece of advice, this passage and those lines about his drivers are the mark of their 'otherness' to him. In other words, what he is doing here is to consolidate his own specialness and his self by creating a division between I-who-have-made-it and You-who-cannot-make-it. In this sense, by alluding to Trinh T. Minh-ha's ideas - in her quasi-poetic book, Women, Native, Other- Gandhi (1998) writes:

By claiming the dubious privilege of "preparing the way for one's more "unfortunate" sisters', the Western feminist creates an insuperable division between 'I-who-havemade-it and You-who-cannot-make-it' . . .. Thus . . . the circulation of the 'Special Third World Women's Issue', only serves to advertise the specialness of the mediating first(?) world woman. (p. 85, emphasis added)

Thus, what is constantly emphasized in his story is the difference between him and 'others': his special-ness, his abilities, his mind, his intelligence, his will, his power, etc. Hence, while for the West there is "a tendency to dichotomise the relationship between the 'Occident' and the 'Orient' into an us-them contrast, and then, to essentialise the resultant 'Other"' (as cited in Gandhi p. 76, original emphasis), here also for Balram there is a tendency to essentialise a resultant 'other'. Therefore, despite Yadav's assertion that "He gave voice to the hushed silence of those silenced people" (p. 6) and rather than being a representative act for the subaltern, his narrative is a story of his own success and a self-consolidating project. Thus, rather than listening to the voice of 'silenced people', as Balram writes, "You are listening to the story of a social entrepreneur..." (Adiga, 2008, p. 104), a thinking man, a WHITE TIGER! Since, as Spivak writes: "For the 'true' subaltern group, whose identity is its difference, there is no unrepresentable subaltern subject that can know and speak itself" (p. 95). That is to say, the moment the subaltern speaks, he or she ceases to be a 'true' subaltern. In this sense, by criticizing Adiga, Deswal also declares that "It seems to him [Adiga] a universal law, that the poor are always crude, helpless, suffering and appalled" (p. 13). This is very evident in young dead man's case where he peacefully writes "The police have let me off. That is the way of this jungle we live in" (p. 188, emphasis added).

Therefore, Balram cannot represent the subaltern neither in regional nor in national levels. Since, on the one hand, as a 'big belly' he is now a member of the dominant group in regional levels; on the other hand, by acquiring a hybrid identity and as a mimic man who values the West over the East he cannot be a true representative for the subaltern, neither in the sense of Marxism nor in post-colonial levels. Hence, his performance in the way to success does not disrupt binary oppositions of thought in the society. In this sense, Lily Want (2011) is so accurate in declaring that the novel does not challenge the paradigms and intellectual premises of Western thought:

"Through Balram's adoption of a distinct social behaviour, he . . participates in the processes by which existing institutions and structures of power are produced. In other words, there is no attempt to alter the existing categories and systems of thought even as he dialectically represents and reinforces class conflict and class distinction" (p. 9, emphasis added)

This valuing of the West over the East is very obvious in his desire for an 'English school', which probably, as Macaulay maintains, will produce a "class of persons Indian in colour, but English in tastes, in opinions, in morals and in intellect' - in other words a mimic man raised 'through our English School"' (as cited in Bhabha, 1994, p. 87), and also is very evident in his assertion that "I'm of half a mind to try one of those skin-whitener creams they've launched these days so Indian men can look white as Westerners" (9), by indicating those western values. Thus, as Guha writes "At the regional and local levels [the dominant indigenous groups]... if belonging to social strata hierarchically inferior to those of the dominant all-Indian groups acted in the interests of the latter and not in conformity to interests corresponding truly to their own social being” (as cited in Spivak, p. 80, original emphasis).

Then, rather than acting in interest of his own social being, Balram is at the service of the center. Thus, even if he gets the power in his hand, as it was in the case of the young dead man, he will not speak justice for the subaltern. This idea coincides with Giorgio Agamben's notion of inclusive exclusion in which he argues that the sovereign authority or colonizer (here the upper class) strengthens its central power through including and affirming the exclusive status of the colonized (here the poor) in its domination: "[t]he inclusion of bare life [Zoe] in the political realm constitutes the original-if concealed-nucleus of sovereign power. It can even be said that the production of a biopolitical body is the original activity of sovereign power" (as cited in Hsi-Lin, p. 3). Therefore, it is in the very existence of biological life that politics finds chance to claim sovereign validity (p. 3). Since, as Foucault also points out "[j] uridical systems of power produce the subjects they subsequently come to represent" and because "[t]he subjects regulated by such 
structures are, by virtue of being subjected to them, formed, defined, and reproduced in accordance with the requirements of those structures" (as cited in Butler, 2011, p. 4), thus, they can never speak for the subaltern.

\section{Conclusion}

To conclude the discussion, we need to highlight, once more, the structures such as Agamben's notion of inclusive exclusion and Foucault's 'producing the agents of domination by the juridical systems of power'. Through such structures and in accordance with their requirements, now, as a 'master of drivers' who has gained power and sees the poor as the 'other', Balram also will not, and cannot speak for them, as it was documented in the young dead man's case. Then, the only thing he can do is, to behave little better than other masters - but if, and only if, it is in accordance with the norms. Thus, he can also be added to the same chain of masters which he considers Ashok one of - a master better than nine in ten-as he writes "As far as masters go, Mr. Ashok, Mukesh Sir, and the Stork were better than nine in ten" (Adiga, 2008, p. 40).

Thus, by examining the novel in this concern, the study concludes that it hardly bears upon the sufferings of the poor, and rather, it is a self-consolidating project. Then all these lead to reach the conclusion that, as Spivak says, "[t]here is no space from which a ... subaltern subject can speak (p. 103).

\section{References}

Adiga, A. (2008). The white tiger. New York: Simon \& Schuster, Inc. Retrieved from physislearningacademy.com/.../1398848071_the-white-tiger-by-arvind-adiga.pdf

Ahmedi, Z. and Rafique, R. (2014). "Use of the Animal Imagery in Adiga's The White Tiger.” 3.2, 522-533.

Bhabha, Homi K. (1994). The location of culture. New York: Routledge.

Butler, J. (2011). Gender trouble: Feminism and the subversion of identity. New York and London: Taylor \& Francis e-Library. Retrieved from https://selforganizedseminar.files. wordpress.com /2011/07/butler-gender_trouble.pdf

Choudhury, M. A. (2014). "Aravind Adiga's The White Tiger as a Re-inscription of Modern India." International Journal 2.3, 149-160.

Deswal, P. (2014). "A Critical Analysis of Aravind Adiga's The White Tiger: A Socio-Political Perspective." Language in India 1930-2940, 275-289.

Evans, D. (2006). An introductory dictionary of Lacanian psychoanalysis. New York and London: Taylor \& Francis eLibrary. Retrieved from www.davidbardschwarz.com/pdf /evans.pdf

Gandhi, L. (1998). Postcolonial theory: A critical introduction. Australia: Allen \& Unwin. Retrieved from https://is.muni.cz/el/1423/jaro2009/SOC711/GandhiPostcolonial.pdf

Homer, S. (2005)."Routledge Critical Thinkers: Jacques Lacan." New York and London: Routledge. Retrieved from https://sites.google.com/site/ikdujfgnthsdvjbjkds/.../Jacques-Lacan-Routledge-.pdf

Hsi-Lin, P. "Performative Others: Sovereign Authority and Subaltern Community in Kiran Desai's The Inheritance of Loss." 1-16.

Maji, S. (2015). "The Subaltern Can Speak: A Study of Arvind Adiga's The White Tiger." IJAR 1.8, 351-352.

Mendes, A. (2010). "Exciting Tales of Exotic Dark India: Aravind Adiga's The White Tiger." The Journal of Commonwealth Literature 45.2, 275-293.

Spivak, Gayatri Chakravorty. "Can the subaltern speak?" 66-111. Retrieved from abahlali.org /files/Can_the_subaltern_speak.pdf

Want, L. (2011). "The Poetics and Politics of Cultural Studies in Aravind Adiga's The White Tiger." An International Journal of Asian Literatures, Cultures and Englishes 5.1, 69-77.

Yadav, R. B. (2011). "Representing the Postcolonial Subaltern: A study of Arvind Adiga's The White Tiger." 2.3, 1-7. 